\title{
Penghambatan Ekstrak Etanol Sereh (Cymbopogon citratus (DC) Stapf ) terhadap Produksi Verotoksin Escherichia coli Verotoksigenik
}

\author{
Gino Nemesio Cepeda*), Ratih Dewanti Hariyadi, dan Supar \\ Laboratorium Teknologi Pertanian, Jurusan Teknologi Pertanian, \\ Fakultas Pertanian dan Teknologi Pertanian, Universitas Negeri Papua \\ Jl. Gunung Salju Amban Manokwari 98314 \\ Diterima 27-02-2009 Disetujui 18-01-2010
}

\begin{abstract}
Citronella was a spicy plant used as seasoning in Indonesian food. It was reported to have antimicrobial activity. Its extract in form of volatile oil prepared by distilation can inhibit the growth of some bacteria. The objective of the research was to know the inhibition of ethanolic extract of the citronella on growth and verotoxin production of verotoxigenic Escherichia coli. The assay of antimicrobial activity was done by using broth dilution and verocell assay. The results indicated that minimum inhibitory concentration of extract can inhibit effectively verotoxin production of verotoxigenic Escherichia coli.
\end{abstract}

Keywords: antimicrobial, citronella, extract, verotoxigenic Escherichia coli

\section{PENDAHULUAN}

Keamanan pangan menjadi perhatian utama oleh konsumen, badan pembuat undang-undang dan industri-industri pangan. Perhatian tersebut ditujukan pada mikroorganisme-mikroorganisme patogen yang menyebabkan keracunan makanan (Adam \& Moss, 1985). Salah satu mikroorganisme patogen yang menjadi perhatian karena banyaknya kasus keracunan pangan adalah Escherichia coli verotoksigenik (Jay, 2000). Galur ini menghasilkan verotoksin yang dapat menyebabkan haemorrhagic colitis, haemolytic uraemic syndrome serta thrombocytopaenic purpura (Adams \& Moss, 1995).

Di Indonesia belum banyak diketahui masalah yang berhubungan dengan keracunan makanan yang disebabkan oleh $E$. coli verotoksigenik, namun demikian dari beberapa penelitian dilaporkan telah diisolasi bakteri tersebut dari berbagai sumber, antara lain dari limbah cair rumah potong ayam (RPA) di Tanggerang dan Parung (Lusiastuti, 1994). Selain itu bakteri tersebut juga ditemukan pada anak sapi yang menderita diare berdarah di peternakan susu komersial dan tradisional yang berada di Bandung, Sukabumi,

\footnotetext{
*Telp: +62986214991

Email: ginocepeda@yahoo.com
}

Cianjur dan Bogor (Kusmiyati \& Supar, 1998), dan pada daging giling (Pramono, 2000). Di Jakarta sebanyak $1 \%$ pasien di rumah sakit yang menderita diare pada tahun 1997 ternyata memiliki bakteri tersebut (Oyofo et al., 2002).

Upaya untuk menurunkan risiko yang diakibatkan oleh bakteri ini dapat dilakukan dengan penggunaan senyawa antimikroba yang berasal dari tanaman. Penggunaan tanaman sebagai sumber antimikroba dalam makanan khususnya rempah-rempah telah lama dilakukan. Rempah-rempah dalam jumlah kecil mungkin tidak memberikan efek antimikroba, oleh sebab itu rempah-rempah harus digunakan dengan konsentrasi yang tinggi dalam bentuk ekstrak (Ray, 2001). Penggunaan ekstrak etanol dari beberapa tanaman rempah dilaporkan memiliki daya antimikroba. Ekstrak etanol buah picung dilaporkan dapat menghambat pertumbuhan E. coli (Anonim, 2007), demikian pula ekstrak etanol Punica gratum sangat aktif terhadap $E$. coli (Duraipandiyan et al., 2006). C. citratus merupakan tanaman rempah yang digunakan sebagai pembangkit cita rasa dalam makanan dan juga dapat berfungsi sebagai antimikroba alami (Fardiaz et al., 1998). Penelitian ini bertujuan untuk mengetahui daya hambat ekstrak etanol sereh terhadap pertumbuhan dan produksi verotoksin oleh $E$. coliverotoksigenik. 


\section{BAHAN DAN METODE}

Persiapan ekstrak etanol sereh. Batang sereh dirajang dengan ukuran panjang $0,5 \mathrm{~cm}$, kemudian dikeringkan dengan pengering beku sampai kadar air mencapai 8-10\%. Sereh yang sudah kering selanjutnya dibuat bubuk dengan menggunakan grinder dan diayak dengan ayakan ukuran 30 mesh. Bubuk sereh diekstrak menggunakan etanol $96 \%$ dengan metode maserasi (Hostetmann et al., 1997). Ekstrak yang diperoleh disaring dan filtrat ditampung. Filtrat diuapkan pelarutnya menggunakan rotary evaporator pada suhu $40^{\circ} \mathrm{C}$ dengan kecepatan 75 rpm selama 2 jam sampai larutan menjadi ekstrak kental. Untuk menguapkan sisa pelarut, ekstrak dihembus dengan gas nitrogen. Ekstrak dimasukkan dalam botol gelap dan sebelum digunakan disimpan dalam refrigerator.

Persiapan kultur bakteri uji. Kultur uji yang digunakan adalah bakteri E. coliO157H7 ATCC43894, dan E. coli yang diperoleh dari koleksi kultur Balai Penelitian Veteriner Bogor, yaitu E. coliverotoksigenik 910 dan 34b serta E. coli O157:K88. Kultur disimpan dalam agar miring pada suhu $6^{\circ} \mathrm{C}$.

Minimum inhibitory concentration (MIC). Pengujian daya hambat ekstrak etanol sereh pada berbagai konsentrasi menggunakan metode difusi sumur (Modifikasi Carson \& Riley, 1995). Sebanyak $25 \mathrm{ml}$ nutrient agaryang mengandung mikroba uji dari fase pertumbuhan akhir dengan jumlah sekitar $10^{5} \mathrm{cfu} /$ $\mathrm{ml}$ dituang pada cawan petri hingga ketebalan $4 \mathrm{~mm}$. Setelah agar membeku, dibuat sumur dengan diameter $6 \mathrm{~mm}$. Ke dalam sumur dimasukkan $60 \mathrm{ml}$ ekstrak dengan konsentrasi $0,10,20,30,40,50,60$ dan $70 \%$ di dalam pelarut etanol $96 \%$. Cawan petri kemudian diinkubasi pada suhu $37^{\circ} \mathrm{C}$ selama 24 jam. Daya hambat diukur berdasarkan diameter zona bening disekitar sumur dengan menggunakan jangka sorong. Penentuan nilai MIC dilakukan berdasarkan data daya antimikroba pada berbagai konsentrasi tersebut dengan menggunakan metode Bloomfield (1991), yaitu dengan memplotkan antara In M (In konsentrasi ekstrak) pada sumbu $X$, terhadap nilai kuadrat zona penghambatan $\left(Z^{2}\right)$ pada sumbu $Y$. Perpotongan antara persamaan yang diperoleh dari regresi linear $Y=a+b X$ dengan sumbu $\mathrm{X}$, merupakan nilai Mt. Mt adalah nilai In konsentrasi ekstrak pada perpotongan persamaan regresi linear dan sumbu X. Nilai MIC adalah $0.25 x$ nilai konsentrasi ekstrak pada titik Mt.
Penghambatan ekstrak etanol sereh

Daya hambat ekstrak terhadap pertumbuhan

E. coli verotoksigenik. Kultur E. coli yang berasal dari fase pertumbuhan akhir diinokulasikan ke dalam erlenmeyer yang berisi $100 \mathrm{ml}$ triptic soy broth (TSB) dengan jumlah sel sebesar $1 \times 10^{3} \mathrm{cfu} / \mathrm{ml}$. Konsentrasi ekstrak etanol sereh yang digunakan didasarkan pada nilai MIC yang diperoleh pada pengujian sebelumnya. Konsentrasi yang digunakan adalah $0 \%$ (tanpa ekstrak), MIC, 1.25MIC dan 1.5MIC. Erlenmeyer yang berisi TSB, ekstrak dan kultur uji diinkubasi pada suhu $37^{\circ} \mathrm{C}$ dalam shaker incubator dengan kecepatan 150 rpm selama 0, 12, 24, 36 dan 48 jam. Masing-masing waktu inkubasi dilakukan penghitungan jumlah koloni dengan metode pour plate (Jenie et al., 1992).

Daya hambat ekstrak terhadap produksi verotoksin. Kultur E. coli yang berasal dari fase pertumbuhan akhir diinokulasikan ke dalam erlenmeyer yang berisi $100 \mathrm{ml}$ TSB (jumlah sel sebesar $1 \times 10^{3} \mathrm{cfu} / \mathrm{ml}$ ). Konsentrasi ekstrak etanol sereh yang digunakan adalah konsentrasi MIC. Erlenmeyer yang berisi TSB, ekstrak dan bakteri uji diinkubasi dalam shaker incubator dengan kecepatan $150 \mathrm{rpm}$ pada suhu $37^{\circ} \mathrm{C}$ selama $0,12,24,36$ dan 48 jam. Masing-masing waktu inkubasi dilakukan pengujian jumlah verotoksin.

Toksisitas verotoksin dalam supernatan kultur bakteri diuji dengan menggunakan metode Vero-cell assay. Sebanyak $10 \mathrm{ml}$ dari kultur TSB disentrifus dalam eppendorf selama 10 menit pada 8000x g pada suhu $4^{\circ} \mathrm{C}$. Supernatan yang diperoleh disaring dengan filter membran ukuran $0.2 \mathrm{~mm}$. Supernatan bebas sel digunakan untuk pengujian toksisitas verotoksin (Palumbo et al., 1995).

Sel vero ditumbuhkan dalam Eagle's minimal medium dengan $10 \%$ Fetal Calf Serum dan gentamicin (100 mg/ml) sebagai monolayer dalam 96-well microtiter plate. Pipet $100 \mathrm{ml}$ suspensi sel vero dengan jumlah sel $10^{5}-10^{6} \mathrm{sel} / \mathrm{ml}$ kemudian dituangkan ke dalam 96 well microtiter plate dan diinkubasi selama 18-24 jam pada $37^{\circ} \mathrm{C}, \mathrm{RH} 96 \%$ dan $5 \% \mathrm{CO}_{2}$. Contoh supernatan bebas sel sebanyak $100 \mathrm{ml}$ dituangkan ke dalam sumur pertama dari 96-well microtiter plate (pengenceran 1:2) dan dilarutkan 2 kali ke arah diagonal plate. 96-well microtiter plate kemudian diinkubasi pada $37^{\circ} \mathrm{C}$. Setelah 48 jam inkubasi, sumur-sumur tersebut diuji sel-sel vero yang hidup dan yang mati dengan menggunakan mikroskop inverter. Respon positif adanya verotoksin adalah jika 50\% dari sel vero mati atau rusak. Titer 
verotoksin dalam contoh dinyatakan sebagai kebalikan dari pengenceran terakhir yang memberikan respon positif (Palumbo et al., 1995).

\section{HASIL DAN PEMBAHASAN}

Minimum Inhibitory Concentration (MIC). MIC adalah konsentrasi minimum yang dapat menghambat pertumbuhan mikroorganisme. Hasil menunjukkan bahwa konsentrasi penghambatan minimum ekstrak etanol sereh terhadap E. coli verotoksigenik 34b, $E$. coli verotoksigenik 910, E. coli O157:K88 dan E. coli ATCC43894 berturut-turut adalah 2,$61 ; 2,78 ; 2,73$ dan $3 \%$.

MIC ekstrak etanol sereh tersebut relatif lebih besar dibandingkan minyak atsirinya. Minyak atsiri sereh dengan konsentrasi $0.14 \%$ dapat membunuh 50\% populasi E. coli $\mathrm{O} 157: \mathrm{H} 7$ dan $1 \%$ minyak atsiri sereh bersifat bakterisidal terhadap E. coli O157:H7 dalam waktu kontak 30 menit (Friedman et al., 2002), 2\% minyak atsiri sereh bersifat bakterisidal terhadap $E$. coli (Hammer et al., 1999). MIC minyak atsiri thyme terhadap E. colisebesar 0.09\% (Hammer et al., 1999). Dari data-data tersebut dapat dilihat bahwa pada konsentrasi minyak atsiri sereh sebesar $1-2 \%$ bersifat
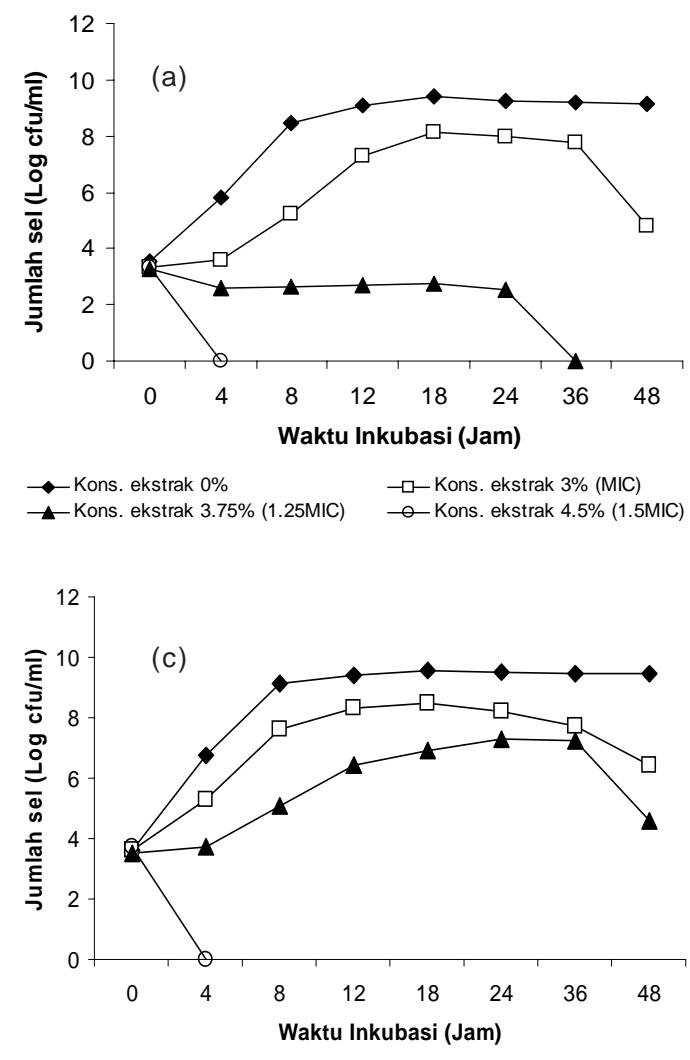

$\begin{array}{ll}\rightarrow-\text { Kons. ekstrak 0\% } & -\square \text { Kons. ekstrak 2.78\% (MIC) } \\ \rightarrow-\text { Kons. ekstrak 3.48\% (1.25MIC) } & - \text { - Kons. ekstrak 4.17\% (1.5MIC) }\end{array}$ bakterisidal terhadap E. coliverotoksigenik sedangkan ekstrak etanol sereh dengan konsentrasi 2.61-3\% hanya bersifat bakteriostatik terhadap E. coli verotoksigenik.

\section{Daya hambat ekstrak terhadap pertumbuhan}

E. coli verotoksigenik. Hasil pengujian menunjukkan bahwa daya hambat ekstrak etanol sereh terhadap pertumbuhan $E$. coliverotoksiganik memiliki pola yang relatif serupa (Gambar 1). Penggunaan ekstrak etanol sereh dengan konsentrasi 2,61-3\% (MIC) dapat menghambat pertumbuhan bakteri uji sebesar 3-5,88 log cfu/ml dan pada konsentrasi ekstrak sebesar 1.5MIC atau konsentrasi 3,9-4,5\% bersifat bakterisidal untuk semua galur uji.

Ketahanan masing-masing galur E. coli verotoksiganik relatif bervariasi. Galur lokal E. coli verotoksigenik 910 merupakan galur yang paling tahan terhadap ekstrak etanol sereh. Konsentrasi ekstrak etanol sereh sebesar MIC (2,78\%) hanya menghambat pertumbuhan sel sebesar 3 log cfu/ml, sedangkan pada galur lain menyebabkan penghambatan pertumbuhan sel sebesar 4,1-5,88 log cfu/ml. Penghambatan pertumbuhan terhadap bakteri uji yang bervariasi tersebut diduga disebabkan oleh perbedaan galur dan
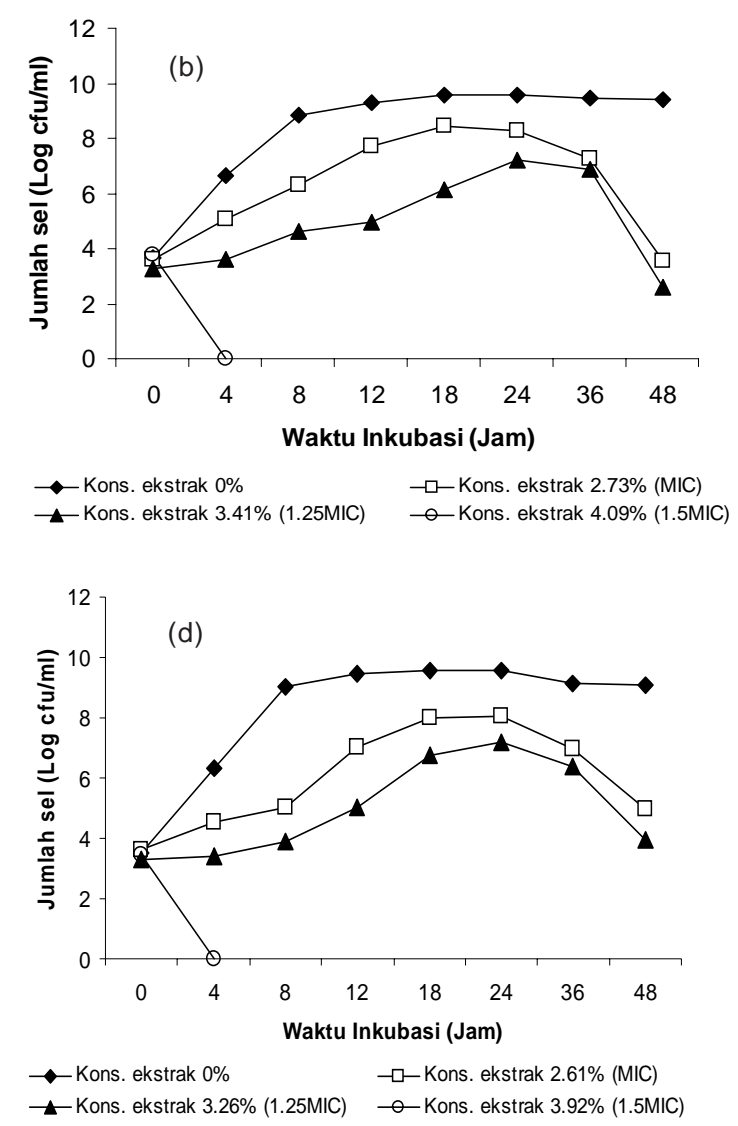

Gambar 1. Pertumbuhan E. coli dalam medium TSB yang mengandung ekstrak etanol sereh :(a) E. coli ATCC 43894, (b) E. coli O157K88, (c) E. coli verotoksigenik 910, (d) E. coli verotoksigenik 34b 
asal lingkungan isolat yang digunakan. Aktivitas senyawa antimikroba bergantung pada jenis dan latar belakang mikroorganisme (Frazier \& Westhof, 1979). Masing-masing galur E. coli yang digunakan, diisolasi dari tempat yang berbeda-beda sehingga akan memberikan respon yang berbeda pula terhadap ekstrak etanol sereh. Konsentrasi ekstrak etanol sereh sebesar 3,9-4,5\% bersifat bakterisidal terhadap semua galur E. coliverotoksigenik.

Produksi verotoksin. Pengujian pengaruh ekstrak etanol sereh terhadap produksi verotoksin dilakukan terhadap dua galur uji E. coli O157:H7 ATCC43894 dan E. coli verotoksigenik 910. Hasil menunjukkan bahwa ekstrak etanol sereh pada konsentrasi MIC dapat menghambat produksi verotoksin E. coli O157:H7 ATCC43894 dan E. coli verotoksigenik 910 (Gambar 2).

Galur E. coli O157:H7 ATCC43894 merupakan galur yang memproduksi verotoksin dalam jumlah tinggi, yaitu 5,72 log titer verotoksin dengan waktu inkubasi 36 jam (Gambar 2a) dibandingkan E. coliverotoksigenik 910 memproduksi verotoksin dalam jumlah kecil, yaitu
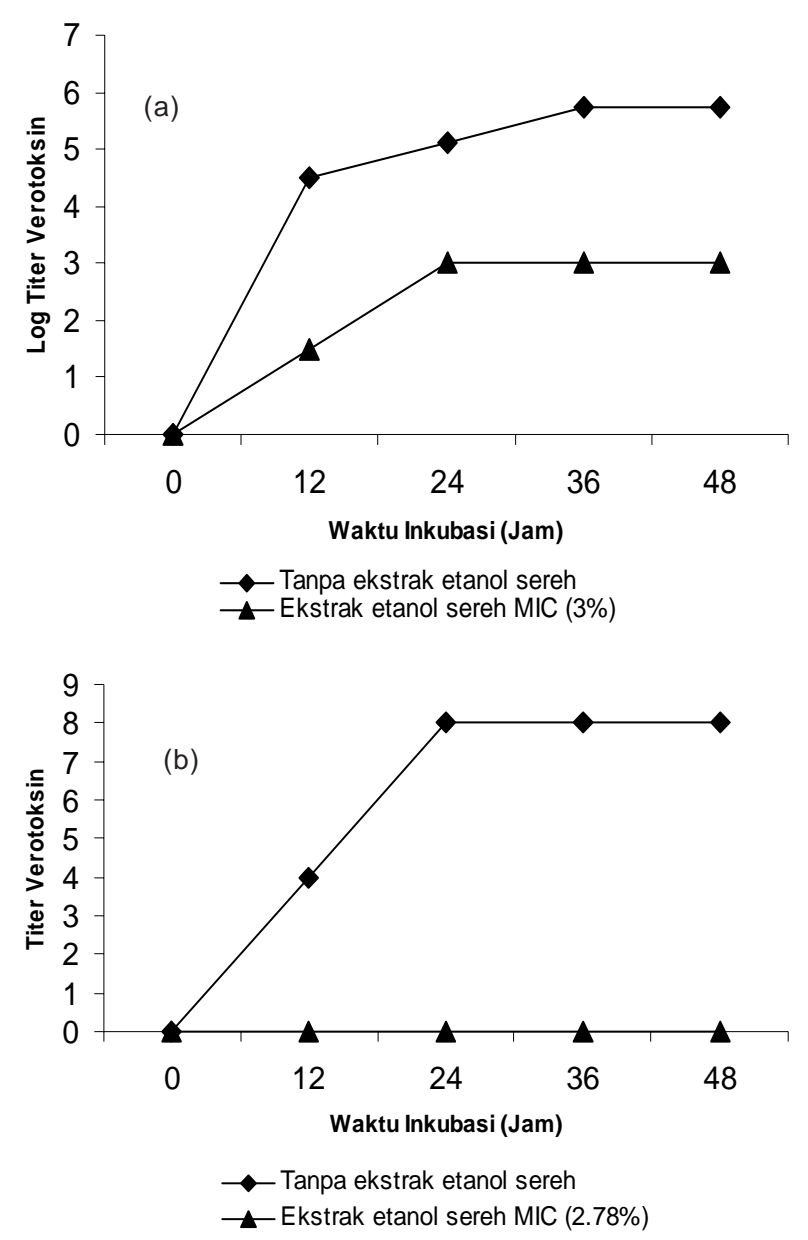

Gambar 2. Produksi verotoksin : (a) E. coli O157:H7ATCC 43894, (b) E. coli verotoksigenik 910
0,9 log titer verotoksin atau 8 titer verotoksin (Gambar 2b).

Perbedaan produksi verotoksin tersebut diduga disebabkan oleh perbedaan galur. E. coli O157:H7 ATCC43894 merupakan galur yang diisolasi dari penderita hemorrhagic colitis (ATCC, 1989), sedangkan galur E. coli verotoksigenik 910 merupakan galur yang diisolasi dari feses sapi. Marques et al., (1989) menyatakan bahwa E. coliO157:H7 dan E. coli lainnya yang diisolasi dari berbagai kasus diare, hemorrhagic colitis atau hemolytic uremic syndrome dan kasuskasus hemorrhagic colitis yang disebabkan oleh keracunan pangan merupakan galur-galur yang memproduksi verotoksin dalam jumlah besar.

Penambahan ekstrak etanol sereh sebesar MIC dapat menurunkan produksi verotoksin dari kedua galur uji. Produksi verotoksin E. coli O157:H7 ATCC43894 dan $E$. coli verotoksigenik 910 tanpa penambahan ekstrak etanol sereh pada waktu inkubasi 36 jam berturut-turut adalah 5,72 log titer verotoksin (jumlah sel $9.21 \mathrm{log} \mathrm{cfu} / \mathrm{ml}$ ) dan 8 titer verotoksin (jumlah sel 9,47 log cfu/ml). Sedangkan dengan penambahan ekstrak etanol sereh sebesar konsentrasi MIC jumlah verotoksin yang dihasilkan menurun menjadi 1024 titer verotoksin (jumlah sel 7,79 log cfu/ml) dan 0 titer verotoksin (jumlah sel 7,74 log cfu/ml). Penurunan produksi verotoksin dari kedua galur tersebut adalah 94,86\% untuk E. coli O157:H7 ATCC43894 dan 100\% untuk E. coliverotoksigenik 910 .

Penurunan jumlah verotoksin yang dihasilkan oleh E. coli verotoksigenik diduga disebabkan oleh kemampuan senyawa-senyawa aktif yang terdapat dalam ekstrak etanol sereh dalam menghambat enzimenzim yang terlibat dalam sintesis verotoksin. Ekstrak etanol sereh dilaporkan mengandung senyawa alkaloid, saponin, fenolik (flavonoid) dan terpenoid (Cepeda, 2009). Senyawa-senyawa fenolik dilaporkan dapat menghambat aktivitas sejumlah enzim (Rhon et al., 2002). Senyawa -senyawa fenolik menghambat aktivitas enzim melalui reaksi yang terjadi antara residu reaktif dari enzim/protein dengan senyawa fenolik (Friedman, 1997).

\section{KESIMPULAN}

Ekstrak etanol sereh dapat menghambat pertumbuhan dan produksi verotoksin semua galur uji E. coli verotoksigenik. Konsentrasi penghambatan minimum ekstrak etanol sereh sebesar $2.61-3 \%$ dapat 
menghambat pertumbuhan bakteri tersebut sebesar 3$5.88 \mathrm{log} \mathrm{cfu} / \mathrm{ml}$ sedangkan konsentrasi sebesar $1.5 \mathrm{MIC}$ (3,9-4,5\%) bersifat bakterisidal untuk semua galur uji tersebut. Konsentrasi MIC dapat menurunkan produksi verotoksin E. coli O157:H7 ATCC43894 dan E. coli verotoksigenik 910 berturut-turut sebesar $94,86 \%$ dan $100 \%$.

\section{UCAPAN TERIMA KASIH}

Ucapan terima kasih yang sebesar-besarnya disampaikan kepada Balai Penelitian Veteriner Bogor atas bantuan bahan penelitian dan penggunaan Laboratorium Bakteriologi selama penelitian, Laboratorium Kimia dan Biokimia Pangan serta Laboratorium Mikrobiologi Pangan Pusat Antar Universitas Pangan dan Gizi, Institut Pertanian Bogor.

\section{DAFTAR PUSTAKA}

Adams, M.R. \& Moss, M.O. 1995. Food Microbiology. Cambridge: The Royal Society of Chemistry.

Anonim. 2007. Ekstrak senyawa aktif buah picung sebagai penghambat bakteri pembusuk dan penghasil histamin. http:/ /rr-1.blog spot.com/2007/08. picng-as-naturanpreervative.html.(10 Agustus 2009).

ATTC, (American Type Culture Collection). 1989. Catalogue of Bacteria \& Bacteriophages. $17^{\text {th }}$ ed. USA:Rockville Maryland.

Bloomfield, S.F. 1991. Methods for assessing antimicrobial Activity. Di dalam: Denyer S P, Hugo WB, (ed). Mechanism of Action of Chemical Biocides Their Study and Exploitation. London : Blackwell scientific Publication.

Carson, C.F. \& Riley, T.V. 1995. Antimicrobial activity of the major components of essential oil of Melaleuca aternifolia. J. Appl. Bacteriol 78:264.

Cepeda, G.N. 2009. Penghambatan ekstrak etanol sereh (Cymbopogon citratus (DC.) Stapf) pada beberapa konsentrasi garam dan $\mathrm{pH}$ terhadap pertumbuhan Escherichia coli verotoksigenik. J. Agrotek 1(4): 9-17.

Duraipandiyan, V., Ayyanar, M. \& Ignacimuthu, S. 2006. Antimicrobial activity of some ethnomedical plants used by Paliy tribe from Tamil Nadu India. BMC Complementary and Alternative Med 6:35.

Fardiaz, S., Triana, A. \& Rahayu, W.P. 1998. Aktivitas antimikroba bumbu segar hasil olahan industri terhadap bakteri patogen dan perusak makanan. J. IImu dan Tek. Pangan 3(2): 1-9.
Frazier, W.C. \& Westhof, D.C. 1979. Food microbiology. New Delhi : Tata McGraw Hill Publishing Co. Ltd.

Friedman, M. 1997. Chemistry, biochemistry and dietary role of potato polyphenols. Rev. J. Agric. Food Chem. 45: 15231540.

Friedman, M., Henika, P.R. \& Mandrell, R.E. 2002. Bactericidal activities of plant essential oils and some of their isolated constituents against Campylobacter jejuni, Escherichia coli, Listeria monocytogenes and Salmonella enterica. J. Food Prot 65: 1545-1560.

Hammer, K.A., Carson, C.F. \& Riley, T.V. 1999. Antimicrobial activity of essential oils and other plants extract. J. Appl. Microbiol 86: 985-990.

Hostetmann, K., Wolfender, J.L. \& Rodrigue. 1977. Rapid detection and subsequent isolation of bioactive constituents of crude plant extracts. Planta Med 63: 2-10.

Jay, J.M. 2000. Modern food microbiology. Maryland: Aspen Publishing Inc.

Jenie, B.S.L., Undriyani,K. \& Dewanti, R. 1992. Pengaruh konsentrasi jahe dan waktu kontak terhadap aktivitas beberapa mikroba penyebab kerusakan pangan. Bul. Pen. IImu dan Tek Pangan III 2: 1-16.

Kusmiyati. \& Supar. 1998. Escherichia verotoksigenik dari anak sapi perah penderita diare. Prosiding seminar hasil-hasil penelitian Bogor. Balai Penelitian Veteriner, Penelitian dan Pengembangan Peternakan, Badan Penelitian dan Pengembagan Pertanian Departemen Pertanian Bogor. Bogor, 18-19 Februari 1998.

Lusiastuti, A.M. 1994. Pengaruh Klorin terhadap Daya Hidup dan profil resistensi antibiotika bakteri fekal koliform dan Escherichia coli $\mathrm{O} 157 \mathrm{H} 7$ dari limbah cair rumah potong ayam. Program Studi Kedokteran Hewan. Bogor: Institut Pertanian Bogor.

Marques, L.R.M., Moore, M.A., Wells, J.G., Wachsmuth, L.K. \& O'Brien, A.D. 1989. Production of shiga-like toxin by Escherichia coli. J. Infect. Dis 154: 338-341.

Oyofo, B.A. et al., 2002. Entheropatogens associated with acute diarrhea in community and hospital patients in Jakarta, Indonesia. FEMS Immun. Med. Microbiol 34: 139-146.

Palumbo, S.A., Call, J.E., Schultz, F.J. \& Williams, A.C. 1995. Minimum and maximum temperatures for growth and verotoxin production by hemorrhagic strains of Escherichia coli. J. Food Prot. 58: 352-356.

Pramono, F. 2000. Evaluasi Media Pengkayaan Selektif untuk mendeteksi Escherichia coli O157:H7 dalam daging giling lokal. Fakultas Teknologi Pertanian. Bogor: Institut Pertanian Bogor.

Ray, B. 2001. Fundamental food microbiology. $2^{\text {nd }}$ ed. New York: CRC Press.

Rhon S., Rawel, H.M. \& Kroll, J. 2002. Inhibitory effects of plant phenols on the activity of selected enzymes. J. Agric. Food Chem 50: 3566-3571. 